doi: $10.19090 /$ i.2017.28.118-133

UDC: $78: 355(497.11)$

ISTRAŽIVANJA

JOURNAL OF HISTORICAL RESEARCHES

$28(2017)$
ORIGINAL SCIENTIFIC PAPER

Received: 15 May 2017

Accepted: 3 September 2017

\author{
MAJA VASILJEVIĆ \\ HARIS DAJČ \\ University of Belgrade, Faculty of Philosophy \\ maja.vasiljevic@f.bg.ac.rs \\ hdajc@f.bg.ac.rs
}

\title{
BETWEEN COURTLY, CIVIL AND MILITARY SERVICE: MILITARY MUSICIANS IN THE PRINCIPALITY AND KINGDOM OF SERBIA*
}

\begin{abstract}
The Principality and later Kingdom of Serbia with its less pronounced class differences, with a thin layer of urban population and the dominance of rural population, was the perfect target for the military musicians that were coming from the Habsburg Empire. "Foreigners" as military musicians would progress into higher strata. Czech musicians were the most important and most numerous among the newcomers in Serbia and the role of Josif Schlesinger as the first important musician is essential for understanding their importance and influence. The educational and modernization process could be followed by the growth in the number of professional military musicians.
\end{abstract}

Keywords: Kingdom of Serbia, military musicians, Czechs, minorities, modernization, civilmilitary relations.

\section{Towards the social history of military musician profession}

$\mathrm{M}$

ilitary musicians played a pioneering role in the development of professional music in Serbia during the $19^{\text {th }}$ century and until the end of the Great War. Yet, this profession did not attract much attention of researchers. The reasons should be related primarily to the orientation of musicology and other humanities towards the development of music within the emerging civil society, but also in an inclination to deny the military musicians practice and importance and quality of their achievements as conductors, i.e. bandsmen that held prominent positions in the cultural life and were involved in the functioning of many organizations, which is also a common approach in

\footnotetext{
* This paper was the result of research on project Modernization of Western Balkans (No. 177009) funded by the Ministry of Education, Science and Technological Development of the Republic of Serbia.
} 
musicology that preferred civil music practices. Therefore, it could be supposed that the position of military musicians at the crossroads of military and civil sectors of the society contributed to their "strangeness" and inaccessibility for interpretation and research. But also, for social historians the insight into this issue is important because military musicians in Serbia were on the intersection of two Empires, the Ottomans and the Habsburgs, in the web of different interest they had to manage and social requirements they had to fulfill.

Therefore, we found "sketches" from the lives of military musicians in Serbia on the margins of music historiographies of the older generation of Serbian musicologists, ${ }^{1}$ with the exception of a few military historians who in their research came across the topic of military musicians in the Principality of Serbia. ${ }^{2}$ In general, during the period of the Principality and Kingdom of Serbia, professional activities of military musicians were related to orchestral instrumental music (band, orchestra, music troops, different names used for military music units), while the performance of choirs was in the spotlight and the music made for them is what attracted the attention of musicologists. We can conclude finally that only sketchy data are available on the military-music profession in this region within military and music history. Until now, only one book was published related to military music and military musicians in Serbia, covering a long period from 1831 to 1945 , in which musicologist Gordana Krajačić collected outstanding archival material from national archives, libraries and other institutions, and also consulted a huge quantity of military and musical periodicals. ${ }^{3}$

In order to achieve the integral historical, musicological and sociological approach to the profession of military musicians in the Principality and Kingdom of Serbia, it is necessary to do huge preliminary research in the voluminous funds of the Military Archive (Vojni arhiv/VA) and in the Archives of Serbia (AS), ${ }^{4}$ but also in local archives, legacies, libraries, especially in the Archive of the Musicology Institute of the Serbian Academy of Sciences (SASA), museums and schools. The sources on musicians were marginal and scarce in all the mentioned archives. The Military Archive in Belgrade is the most important place where documents needed for research of military music profession are kept, but only data on military musicians that were a part of officer corps, i.e. those who held higher positions of conductors or band masters (class IV to I), those who held a lower officer rank of captains (II and I class), and in some cases a higher officer rank, for instance that of lieutenant colonels. The data on all musicians of lower ranks are not kept in the sources of the Military Archives, but only mentioned in relation to officers. From that point of view, our future research could mostly deal with military musicians-officers who formed a part of the elite of their time. Also, first we should focus on studies of the most prominent military musicians in the said period, namely of: Josif Schlesinger (1794-1870), Dragutin Čižek

\footnotetext{
${ }^{1}$ Krajačić 2003; Pejović 1991, 1996, 1997; Đurić Klajn 1977, 1980.

${ }^{2}$ For instance Marković 1957: 28-36.

${ }^{3}$ Krajačić 2003.

${ }^{4}$ VA, fund of the Army of the Principality/Kingdom of Serbia 1847-1920; AS, the fund of the Ministry of Education and Religion. See a list of sources at the end of this paper.
} 


\section{$(1831-1913){ }^{5}$ Dragutin František Pokorni $(1868-1956)^{6}$ and Stanislav Binički $(1872-1942){ }^{7}$}

An early and only example of understanding the importance of military musicians in the Principality and Kingdom of Serbia was a "lexicon" publication of the nowadays neglected composer and ethnomusicologist Vladimir R. Đorđević (1869-1938), who was a contemporary of the musicians that are the subject of this paper. In 1922 Đorđević published the biographies of musicians in the magazine Muzički glasnik (Music Herald), which was later collected into a lexicon Prilozi biografskom rečniku srpskih kompozitora (Contributions to the Biographical Dictionary of Serbian Composers) ${ }^{8}$ and proved to be worthwhile for our research since he also showed a sociological interest in the music profession of $19^{\text {th }}$ and early $20^{\text {th }}$ centuries. In other words, while collecting data on musicians, although sometimes inconsistent and biased, Đorđević paid special attention to the problems they were encountering, their salaries in civil and military institutions, their relations with authorities, their marital status, and finally their change of religious

${ }^{5}$ Čižek came from a military family and was born in the Czech Donji Berškovic. He became a military musician in the $39^{\text {th }}$ infantry regiment in Prague, where he worked until 1864, when he was moved to Zemun with the $28^{\text {th }}$ rifleman regiment. Besides the regular military academy, he also learnt from the bandmaster Rosencrantz. Throughout his career he was a bandmaster of military music and simultaneously worked in the Belgrade gymnasium and as a conductor of the Royal Serbian National Theatre in Belgrade. He composed piano and instrumental orchestra music. He introduced string instruments into military bands in Serbia, which had previously consisted exclusively of wind instruments, and in that way made military bands of the Kingdom literally modern orchestras: Đorđević 1950: 62-63; Krajačić 2003: 27-29, 125.

${ }^{6}$ D. F. Pokorni originated from a music and military family, studied the French horn at the Vienna conservatory, did his army service at the Vienna military band and before coming to Belgrade used to work as a rehearser and French horn player in the Carltheater. On two occasions, 1897-1904 and 1906-1910, he was a conductor of the Royal Serbian National Theatre in Belgrade and "Boulevard Opera" of Žarko Savić. He was not only a headmaster of the military musical school in Grejač, but also continued the same activity in Africa and after the war he founded the Military musical school in Vršac in 1919 and started courses for bandmasters in 1929. He founded the Central musical archive at the Serbian army and navy. He held a post of the Head of military bands 1920-1937 and, simultaneously, he was a kapellmeister of the Royal Guard Orchestra. He composed a score of pieces that, unfortunately, musicologists did not analyse so far. See more in: Krajačić 2003: 69-71; Vasiljević 2014: 22-23.

${ }^{7}$ Binički was a prominent Serbian composer and conductor, military and civil bandmaster, the author of the first performed Serbian opera Na uranku in 1903 and the "creator" of dynamism in the music life of pre-war Belgrade, where he first conducted the Belgrade Military Orchestra in 1899-1903 and from 1904 the Royal Guard Orchestra. Just before the Great War, Binički founded the Serbian music school "Stanković" with the Music society "Stanković" that had its own orchestra. As a conductor, he presented the premiere of the Ninth symphony (1824) by Ludwig van Beethoven and of Haydn's oratorio The Creation (Die Schöpfung, 1797/8), and that was considered an exceptional success of Serbian music. In accordance with the tendencies of West European bel epoque Binički advocated concerts in pubs, restaurants, open air concerts at Kalemegdan and Topčider (see Pejović 1966, 1991; Stojanović 2008: 288-297). On his biography further details in: Krajačić 2003: 33-68; 105-106. He played a crucial role in the professionalization of military bands in Serbia and, judging by his file in VA, it was his merit that many of his musicians were sent abroad for further professional development. As a person in charge of all military bands and as a kapellmeister of the Royal Guard Orchestra, he spent the Great War close to the Serbian government since Corfu. In Thessaloniki he organized concerts with the surviving musicians, both civil and military, and a tour of France (Vasiljević 2014; Vasiljević 2014).

${ }^{8}$ Đorđević 1950. It is not entirely clear why Đorđević omitted Josif Schlesinger in this lexicon, where he included numerous Czech musicians in the list of "Serbian" musicians. 
denomination or even more often their names in order to achieve a more favorable status in the society. That kind of data, however, is not to be found in subsequent encyclopedias on Serbian or later on Yugoslav music.

This paper provides steps for a possible sociological approach to the military-music profession which will be based first on archive research and then on theoretical knowledge of the process of modernization, migrations and civil-military relations.

\section{At the crossroads of Empires: \\ Migrations of musicians into the Principality and Kingdom of Serbia}

Before understanding the development of the military music profession from a point of view of music migrations of professional musicians from the Habsburg monarchy, it is important also to follow complicated social circumstances from the 1870 s to 1918 with numerous conflicts that ended in the Balkan wars (1912-3) and the Great War (1914-1918). At the one hand, this brought many opportunities for military musicians to get killed or wounded. On the other hand, under such circumstances they were given a chance to get higher posts much faster or to change service too often. Besides, after the end of each of the mentioned wars, there was again a problem of insufficiently educated musicians to reestablish new generations of young trained musicians, especially current for Serbia.

From that point of view, it seems that the first crucial fact in the $19^{\text {th }}$ century process of music migrations to Serbia was the territorial increase and international recognition of the Principality of Serbia as an independent country at the Berlin Congress in 1878, which imposed a need for faster education of a large number of young officers and a reform of the military school system. ${ }^{9}$ Since neither military nor civil music education existed at the time ${ }^{10}$ that implied an increased need for educated musicians from outside of Serbia, so it explains why after 1880 the largest number of Czech musicians came into the country. What is very important, most of them came with an experience in the Austro-Hungarian army. ${ }^{11}$

The migrations of Czech musicians started in 1844 and culminated in the period from 1860 to 1890 , lasting until $1918 .{ }^{12}$ Czech musicians were mostly coming to Vojvodina, but they also crossed to the other side of Danube, leaving the Habsburg Empire. A significant

\footnotetext{
${ }^{9}$ Further on military schools in Serbia: Zorić i Đukić 2010.

${ }^{10}$ The first military music school was founded in the village Grejač close to Niš just before WW I, led by the Czech Dragutin F. Pokorni, but young cadets soon had to retreat with the Serbian army, so not many of them managed to survive to the Tunisian port of Bizerte, where the school continued to operate (More details in: Vasiljević 2014: 130-132). On general music education there are certain data (Đurić Klajn 1980: 97-117; Gavrilović 2012).

${ }^{11}$ For example, Josif Ce from the Czech town of Trnovo, a graduate of the prestigious School of organ playing in Prague, as a kapellmeister in the Austro-Prussian War, took part in the battle at Königgratz in 1866, the one where the Austro-Hungarian army suffered epic losses, so he had to retreat arduously with military musicians. After that disaster came many cuts in the army, so Ce was fired and went to Pančevo and Zemun, from where he crossed to Serbia 23 years later and worked as a kapellmeister in Kragujevac, according to: Đorđević 1950: $59-60$.

${ }^{12}$ It is considered that after the establishment of the first court orchestra in Kragujevac in 1829, the Pančevo singing society in 1838 and after the first concert was performed in Belgrade in 1841, people became interested in the development of music life like in other European courts and urban environments (Pejović 1996: 52)
} 
number of Czech musicians came to Serbia since the late 1860s, when the Austro-Hungarian Empire was formed, but at the same time emerged a network of important cultural institutions in Serbia, starting with the National Theater in Belgrade in 1866, which increased the need for educated musicians. In the Principality of Serbia they held the following posts: choirmasters, music teachers, instrumentalists (they also performed as soloists and members of the chamber instrumental groups or military bands), composers and military band masters (conductors). ${ }^{13}$ The cities that Czech musicians mostly came to were: Vršac, Kikinda, Novi Sad and Pančevo, while in Serbia that was Belgrade. In 1868 the first Czech society in Serbia was established, but it was right away closed. Then, in February 1885 in hotel "Bajloni" in Belgrade near the Railway station, the Czech society "Lumir" (Český spolek Lumir) was founded under the name of the cultural and educational society of Czech and Slovaks in Belgrade. As a forerunner of today Belgrade „Češka beseda", within "Lumir" there was a library and a puppet theater; music, singing and theater sections and, of course, the folklore section.

If we explore the social origin of military musicians, that indirectly opens up the social problem of migrations and significant social changes they produced. Furthermore, it is customary that, while investigating migrations, sociologists discuss the issue of cultural transfer and for Czech musicians that topic is very interesting. Czech-born musicians brought to Serbia a foreign language and simultaneously a rich production of choir music adapted to the local language that they had just become familiar with, which was very important for the study of the history of music in the regions that Serbs inhabited. AustriaHungary had a multitude of different language varieties, so the problems of encountering different languages were common, although in many regions of the Dual Monarchy the official language was German. On the contrary, in the Principality of Serbia, which fought for the independent language and cultural transfer, the context was different. In general, Czech musicians "as Slavs they corresponded to cultural requests of the Serbian nation and its resistance to Germanization and Hungarization". ${ }^{14}$ In the Principality of Serbia a process of language standardization was still in progress and "diglossia" was noticeable, i.e. there was undoubtedly a large gap between sparse educated urban population and the uneducated who spoke the rural variety. According to the insight into biographies and archive documents on military musicians, we can conclude that military band masters who settled in the Principality of Serbia were forced to learn the Serbian language and quite often they switched to the Orthodox religion, which is something that became a common practice in the Kingdom of Serbia. ${ }^{15}$ The practice of insisting on local born musicians first came when

\footnotetext{
${ }^{13}$ Compare with: Pejović 1996: 51.

${ }^{14}$ Pejović 1996: 52.

${ }^{15}$ For instance, Miloš Julije Brož (1860-1912) was born in Lhota in Moravia, where his father was a headmaster of a local school and led a choir. He studied at the teacher training college and the School of organ playing in Prague. He took an exam of a choirmaster and singing teacher so he could serve in the Austrian military band from 1882 to 1884 . In 1884 he came to the Kingdom of Serbia to work in the Teacher training college at Aleksinac. He switched from the Catholic to Orthodox religion and later worked in Belgrade, Southern Serbia, Valjevo, etc. according to: Đorđević 1950: 5. Also, Avgustin-Aleksandar Valenta (1859-1935) from the Czech city of Plzeň came to the Kingdom of Serbia in 1882 after the gymnasium and music school in Prague; he changed his name (became Aleksandar) and switched from the Catholic to Orthodox religion (6). See files in the frame.
} 
the first court orchestra was founded with Josif Schlesinger as their band master ${ }^{16}$ at the time of Prince Miloš Obrenović. Efforts were noticeable to include Serbian young men, which implies anxiousness that educated foreigners would have a dominant role. In the meantime, a complex process of the so-called "elite planning" through the state support of education started in the Kingdom of Serbia and almost eliminated the influence of foreigners in the music sphere until the end of the Great War. ${ }^{17}$

It was just recently that a consensus was reached in musicology, although it did not focus on the history of the $19^{\text {th }}$ century that much, on how Czech musicians should be treated, ${ }^{18}$ for they were treated as foreigners for a long time and then a conclusion was reached they were the same as Serbs, the citizens of a multiethnic, multilingual state, the Austro-Hungarian monarchy, and they simply moved looking for jobs. ${ }^{19}$ From the files of military musicians and a few published biographies of Czech musicians in our country it is obvious that many of them responded to musician job invitations published in magazines in Czech and German.

Insight into the records of the Military Archive and the Archives of Serbia undoubtedly confirmed that when applying for jobs in the Principality and Kingdom of Serbia Czechs as candidates first had to pass committee exams for musical service and to present a certificate on the "release from citizenship" and then to "give oath for Serbian citizenship", in other words to become citizens of Serbia. ${ }^{20}$

The key question that emerges regarding the migration of Czech military musicians is still a reason for their arrival. Judging by the research of an eminent Hungarian-American historian of the Habsburg military history, István Deák, the officers in the Austro-Hungarian army in 1868 had salaries almost equal as state clerks, while their salaries fell significantly in $1899,{ }^{21}$ when officers' salaries were much below those of state clerks. That was anonymously condemned in periodicals, so for instance, in a reputable military magazine Armeblätter probably an officer or a journalist from a military family asked himself: "What

\footnotetext{
${ }^{16}$ On creating this orchestra, see: Marković 1957: 28-36.

${ }^{17}$ On the complex process of diplomatic efforts of the Serbian government and the prime minister Nikola Pašić to send students and scientists to leading world centers see: Mitrović 2004: 241-255; Trgovčević 1986. Actually, after the retreat to Corfu, the Ministry of Education organized sending students to France, Great Britain, Russia, Italy and Switzerland.

${ }^{18}$ For instance, V. R. Đorđević treated musicians of Czech origin as "Serbian", since they worked on the territory of the Kingdom of Serbia (compare: Đorđević 1950). The most prominent musicologist of an older generation, Roksanda Pejović, at first considered them foreigners and excluded them from research (Pejović 1991), but studied them later separately and emphasized their significance for Serbian culture (compare: Pejović 1996; 1997).

${ }^{19}$ Gajić 2009; Tomašević 2006.

${ }^{20}$ Compare: Kapellmeister of Czech-Italian origin, Friedrich (Federico) Brunetti submitted documents on the release from Austro-Hungary in 1844 and on giving oath on 27 February 1865. These documents were signed in 1865 by the current minister of internal affairs Nikola Hristić: Archives of Serbia, Fund of the Ministry of Education, file 32, doc. 132-1904. Although there is a range of similar document submissions on "citizenship" there are exceptions. So, for instance, Josif Ce (1842-1897) as a prominent military kapellmeister in the AustroHungarian army, who worked from 1867 to 1897, first 23 years in Vojvodina (Pančevo, Zemun), then in Kragujevac, where he worked in a gymnasium and a girls' college, did not have to take Serbian citizenship (Đorđević 1950: 60).

${ }^{21}$ Compare data in Table 5.4. compiled by István Deák (1990).
} 
kind of a country values a clerk more than a soldier?"22 Judging by the research of archival material it is clear that one should get a higher rank (promotion) and therefore a higher salary in the Austro-Hungarian, than in the Serbian army. ${ }^{23}$ Anyway, it looks very probable according to the available material that a need for musicians was much more present among officers in the Kingdom of Serbia; more specifically, it is highly probable that Czechs with moderate education increased their chances to get a job in various sectors by coming to the Principality-Kingdom of Serbia: choirs, schools, military bands, since the competition was not that high. A quest for experienced musicians, therefore, brought about experienced protagonists from the Austro-Hungarian army and that matches what can be found in available biographies of military musicians.

Having gained insight into the salaries of civil and military music clerks, i.e. by the comparison of data from the fund of the Ministry of Education (AS) with the results of excessive quantitative research of officer salaries of the historian Mile Bjelajac, ${ }^{24}$ it can be concluded that the salaries of junior officers were much higher than the salaries of teachers of music and sheet singing or choirmasters and matched only those of junior officers and conductors in the prestigious Royal Serbian National Theatre in Belgrade.

Actually, a junior officer in 1886/1887 had the following annual salaries: potporučnik (second lieutenant) 1516, poručnik (lieutenant) 1920, kapetan (captain) 2274, kapetan I klase (senior captain) 2779 (next higher officer rank, major, had almost twice that salary, 4042, all the way to 7073 for pukovnik - colonel), and in 1889 they had following annual salaries: potporučnik (second lieutenant) 1800, poručnik (lieutenant) 2200, kapetan (captain) 2600, kapetan I klase (senior captain) $3150 .{ }^{25}$ Judging by different salaries in high schools and gymnasia that in the 1880s ranged from 500 for village schools to 1500 annually for music teachers in the Kragujevac gymnasium, we can conclude that even the most junior officer rank (second lieutenant) was better paid than an average music teacher. One important thing that should be emphasized is that military band masters with almost no exception worked in parallel in civil institutions, i.e. schools, theaters, choirs, which meant that the said military salaries were supplemented by a salary from another civil institutions. ${ }^{26}$ If officers' income was satisfactory, an assumption can be made that they were used to an extravagant lifestyle, the same as their counterparts in the Austro-Hungarian army. As a result, officers were forced to take several posts. Research on the lifestyle of the elite in the Principality and especially in the Kingdom of Serbia would answer that, but unfortunately it was never done.

${ }^{22}$ Ibid

${ }^{23}$ Compare: Deák, 1990; Čapo, 2009; Bjelajac, 1999.

${ }^{24}$ Bjelajac 1995.

${ }^{25}$ Bjelajac 1995: 27.

${ }^{26}$ See: Correspondence on jobs between Friedrich Brunetti, Vladimir Štirski, Julije C. Brož and František (Dragutin) Pokorni in: Archives of Serbia, Fund of the Ministry of Education, folder 49; Correspondence on jobs (during and after his studies and scholarship) of Stanislav Binički: AS, Fund of the Ministry of Education, f. 18; Correspondence on jobs of Stevan Šram: AS, Fund of the Ministry of Education, f. 50; Correspondence on jobs of F. Bruneti; AS, Fund of the Ministry of Education, f. 8; Correspondence on jobs of Hink Maržinec: AS, Fund of the Ministry of Education, f. 37. See correspondence on job issues by D. F. Pokorni in the Sixth infantry regiment "King Karol I" and simultaneously as a conductor of the Royal Serbian National Theatre in Belgrade from 1901; AS, Fund of the Ministry of Education, f. 8, doc. 80-1902. 
Still, one should not ignore the significance of a growing consciousness regarding the national state among Serbs and from that point of view the position of Czech musicians in Serbia should be considered. Trgovčević's conclusion was that education in the $19^{\text {th }}$ century "in the majority of modern societies became compulsory and therefore accessible to all citizens; it opened up possibilities for mobility within the society, i.e. a change of the social status and their participation in public, cultural and political life", and in that process the school played an "important role in shaping citizens... it linked them to a nation."27 Czech musicians, therefore, had different ways of accepting assimilation into the growing Serbian nation by changing their religion, language, name and, finally, receiving citizenship. They became "our foreigners", ${ }^{28}$ but an obvious later process of emphasizing separate "Yugoslav" ideas or specific national programs in the Kingdom of Serbs, Croats and Slovenians/Yugoslavia gradually displaced them or at least "moved" them to a less important position and that is confirmed by a total exclusion of Czech musicians from later research until the present day. Military musicians possessed financial and cultural capital, so only symbolical capital could have been missing in case they aspired towards the recognition in civil music, but that depended on a number of factors.

\section{Military musicians in the complex civil-military relations}

The history of military music is simultaneously a political and military history, so we can say that each novelty in this area appeared at the times of some important political upheaval, i.e. a significant social change. For instance, the disbandment of the Belgrade Military Orchestra in 1903 after the May Coup, or the founding of the Royal Guard or the already mentioned forming of an orchestra at the court of prince Miloš after the Second hatt-i sharif in 1833 .

Military musicians as a separate group within the military elite can be a topic of sociological research for they bring out the treatment and "conduct" of foreigners/minorities in a military hierarchy and civil-military relations. Quite similar to the case of studying the modernization process, basic studies, as for instance The Soldier and the state, 1957, by Samuel P. Huntington, ${ }^{29}$ are based on the Western European model, but in case of military history they all follow very significant phenomena of the history of intertwining between the civil and military factors, and relations are interpreted primarily through political and economical lenses. Anyway, for the research of a specific military service of military musicians, Huntington expectedly did not provide enough data, even when he investigated crucial changes in the military profession regarding "born talents" in the theories (Prussian and English) of the $18^{\text {th }}$ century and the development of the modern soldier who studied skills. Musicians were, again, certainly the only kind of service that was regularly present in the civilian life and at war times became a specific link between two different worlds. As a specific example of a local, independent relation between civilian and the military we

\footnotetext{
${ }^{27}$ Trgovčević 2003: 10.

${ }^{28}$ Musicologist Ivana Vesić pioneered the concept of "our foreigners" concerning the positioning of the Slovenian Davorin Jenko, see: Vesić 2013.

${ }^{29}$ Huntington 1985.
} 
could use the experience of military band masters from the Balkan Wars (1912-1913) and specially from the Great War, when, after leaving the territory, military bands in that new context had the role to preserve identity, reminded soldiers of the homeland, linked surviving civilians - musicians of military bands played for humanitarian but also for diplomatic reasons, and their band masters made contacts with elite representatives of societies of the ally countries.

The increase of intertwining of the civil and military service in the profession of military musicians was confirmed and allowed. Insight into the archive funds of the Ministry of Education of the Kingdom of Serbia ${ }^{30}$ gave us a clear picture of the practice where military musicians simultaneously with military (music) service, worked and received regular civil salaries from gymnasia and high schools, as well as choirs and theaters in the Kingdom of Serbia. It was noticed that the practice of employing military musicians in civil institutions was questioned for the first time when the Belgrade Military Orchestra was formed in 1901, since it was obviously a competitor to theater and military bands of the time, for it is a fact that the best performers accepted an invitation by Stanislav Binički, a founder and conductor, to join the Belgrade Military Orchestra. ${ }^{31}$

The profession of a military musician in the Kingdom of Serbia was marked by foreigners, who in time became "our foreigners". ${ }^{32}$ In the early phase of migrations they undoubtedly were better educated than local soldiers-musicians. Anyway, as a part of the officer corps, military band masters were also part of the military elite. They could not reach the very top of military hierarchy, general headquarters (generals, field marshals, admirals), but still held high positions in the society because of their salaries, and their access to resources (especially at the time of military conflicts that were then and brought about a quicker promotion of military musicians). Still, we emphasize that just a few musicians in the mentioned period could have access to resources and join the elite, eventually as clerks of the Ministry (something Petar Krstić achieved in the period between two world wars). It should be noted that musicians who found their way into the elite mostly came from the ranks of professional military musicians. Military musicians in the Principality/Kingdom of Serbia were characterized by: origin from a military family, high education (knowledge of foreign languages which significantly facilitated diplomatic correspondence at the time of the Great War), ${ }^{33}$ advantageous financial position (salaries in the army), and not

${ }^{30}$ Correspondence on jobs between Friedrich Brunetti, Vladimir Štirski, Julije C. Brož and František (Dragutin) Pokorni in: Archives of Serbia, Fund of the Ministry of Education, f. 49; Correspondence on jobs (during and after his studies and scholarship) of Stanislav Binički: AS, Fund of the Ministry of Education, f. 18; Correspondence on jobs of Stevan Šram: AS, Fund of the Ministry of Education, f. 50; Correspondence on jobs of F. Brunetti; AS, Fund of the Ministry of Education, f. 8; Correspondence on jobs of Hink Maržinec: AS, Fund of the Ministry of Education, f. 37.

${ }^{31}$ Complex correspondence of military institutions, schools where they worked, and especially the Royal Serbian National Theatre in Belgrade reveals that significant problems occurred in 1899: AS, Fund of the Ministry of Education, f. 7, doc. 80-1902.

${ }^{32}$ Serbian musicologist Ivana Vesić used the term "our foreigners" in the research of positioning and treatment of the Slovenian composer Davorin Jenko, see: Vesić 2013.

${ }^{33}$ As a prominent example of relations between military musicians and the political and military elite we can take D. F. Pokorni, who stayed in the Tunisian port of Bizerta during World War I and in his humanitarian activities made acquaintance with leading political and military persons of the Maghreb countries (National Library of 
infrequently marriage with spouses whose fathers belonged to the economic, military and political elite. The only thorough research of military elite of the time is the one performed by historian M. Bjelajac. Bjelajac's research on marriages of officers was conducted regardless of their service and on a large sample. His central conclusion based on quantitative research brought about knowledge that through marriage officers mostly connected to the sparse economic elite (industrialists and the like) and then with the political one, while less often they picked spouses from well-off merchant families and other private professions (pharmacists, lawyers, etc.) ${ }^{34}$ due to various factors, the most important one being a legal financial restriction for officers to marry women belonging to lower social strata in order to preserve the prestige of the officer profession. ${ }^{35}$ Besides, it is noticeable that prominent musicians, both civil and military, were recruited to mason lodges (for instance Binički, Pokorni, Mokranjac).

It is therefore very important that military musicians, i.e. junior officers, according to different social practices could become close to the representatives of the political and economic elite. We consider those connections with the political and economic elite very important or crucial for profiling officers/military musicians and a significant determinant in defining the civil-military relations in the societies of the Principality and Kingdom of Serbia. It is important to highlight this because musicians and all other intellectual professions had a rare opportunity to become the elite members of the society.

\section{Military musicians and the modernization process in Serbia}

The modernization process, judging by the historian Meri-Žanin Čalić, took somewhat a different path than in the developed West European countries and had legal obstacles that slowed down modernization. ${ }^{36}$ The historian Dubravka Stojanović followed the modernization process primarily in Belgrade and summarized the conclusion of M. Ž. Čalić, who wrote in her study Social history of Serbia 1815-1941 (Socijalna istorija Srbije 1815-1941):

Serbia, Department of special funds, Archive of Dragutin Pokorni, R-210). In his legacy we found correspondence (in several global languages) with the mayor of Algiers Charles de Galland, who was a great fan of music and the biggest reformer, statesman and politician of Algeria. Also, based on personal acquaintance with admiral Émile Guépratte, he made many tours of the Magreb countries and affected a consequent accolade this retired French citizen received. For more details on the diplomatic activity of Pokorni in Africa, see: (Vasiljević 2014). As a Head of military music during the Great War, S. Binički also made contact with numerous ally members of the political and military elite he was a guest at celebration of French victory of 1916; with the Royal Guard Orchestra (more in: Vasiljević 2014; Vasiljević 2014).

${ }^{34}$ See: Bjelajac 1996.

${ }^{35}$ Military bandmasters married educated, often highly educated spouses from wealthy families of the sparse economic or political elite in our country. The most prominent one, Binički, married a colleague from music studies, a German singer Frida Blanke, who changed her name to Miroslava Binički after arriving to Belgrade. In addition, his mother was an Austrian Baroness.

${ }^{36}$ Regarding modernization in Serbia, see: Čalić 2004; Perović 2001; Stojanović 2008; Stojanović 2010; Trgovčević 1994, 2003. On different paths of the countries in Southeast Europe, see: Berendt 2003; Chirot 1991. 
Serbia, as other societies in the Balkans, did not follow the path that can be called late imitation of the Western development route, but during its modern history it built its own path in the cultural, historical, social and economic sense. ${ }^{37}$

Stojanović also adds that Serbia:

In the modernization of its institutions it did not scruple over drastic innovation cuts, but was not ready to apply similar moves on the society and accelerate its abandonment of the pre-modern stage. ${ }^{38}$

Therefore, in the century marked by a slowed-down modernization, the most significant influence on music were the migrations of Czechs, which played a very important role in the process of professionalization of music towards the end of the Great War (as was, for example, the role of Russian musicians after 1917), which implied raising the criteria for successful modernization of a certain environment, also possible by the spread of education. Besides literacy music education also required learning the so-called kajdopis or, in modern terms, the musical alphabet. Local, i.e. ethnic Serbs entered music life in urban centers of the Kingdom of Serbia mostly after the first wave of state support in the form of education abroad, or in cases where the state paid for scholarship fees. ${ }^{39}$ Besides, the majority of prominent military musicians came from wealthy Czech families that could afford education at prestigious institutions of that time, like the Music Conservatory and the Organ School in Prague.

Regarding the modernization process in the 19th century Serbia, Lj. Trgovčević formed a basis for further research, collected and systemized data on scholarships and students attending foreign universities ${ }^{40}$ and it should be emphasized that the mentioned process reached a kind of culmination during the Great War when many musicians left the country in a huge migration process which took them to the Allied countries of Greece, France, Great Britain, Tunisia, Switzerland, Russia, etc. ${ }^{41}$

In the pages to follow, we offer a retrospective of this arduous and long process of reaching education and of the gradual formation of the "tertiary" and more complex social structure of society in the Kingdom of Serbia. Regarding music, it is interesting that every breakthrough of professionalism, the appearance of every notable person or the establishment of certain music institutions coincided with the ideology of ruling politics, i.e. the support of educational policy by the government and the elite.

${ }^{37}$ Čalić, according to Stojanović 2008: 174.

${ }^{38}$ Ibid. 174.

${ }^{39}$ Only a few musicians attended schools at their own expense, for instance the most prominent military and civil musician Stanislav Binički (1872-1943), born in a village Jasika near Kruševac, the son of a colonel of the Austro-Hungarian army and industrialist, Stevan Binički (see news on his return from studies and on family Binički: Večernje novosti, 25. 07. 1899, No. 202). On the side of his mother (baroness Maria von Rehingen) he had Austrian noble ancestry (see: Legacy of Stevan and Stanislav Binički, National museum of Kruševac, Photography collection). The list of musicians receiving scholarship from the state is impressive, but unfortunately the number of those that obtained a diploma after their studies abroad is significantly smaller. Talking about that, it should be noted that many musicians studied abroad for some time, for instance Stevan Stojanović Mokranjac.

${ }^{40}$ Trgovčević 2003.

${ }^{41}$ Mitrović 2004. 
Anyway, the whole $19^{\text {th }}$ century and the period until the end of the Great War was marked by a battle for education and a simultaneous migration of educated citizens from other parts of Austro-Hungarian monarchy. Trgovčević highlights:

\begin{abstract}
Education is one of the basic features that make a difference between the modern and traditional society. Most characteristics of the modern or technological era originated from a larger amount of knowledge and its wider application in different forms of human activity, and from a more developed capability to embrace the knowledge by a wider range of social strata. Many theories on modernization that appeared in last decades of the $20^{\text {th }}$ century emphasized the importance of education, not on its own but because its spreading produces the majority of characteristics of a modern society (a high rate of literacy, technological revolution, social mobility, professionalization of jobs, communication via different media...). Many researchers examined the modernization processes in developed societies and on their examples built the existing theories and applied the phenomenon within a period when it occurred in those societies - the second half of the $19^{\text {th }}$ century. That is the time when the domination of rationalism and a significant increase of different knowledge started and, therefore, the advancements in science and education. (...) The $19^{\text {th }}$ century is also the age of shift in freedoms and human rights and within civil rights that were conquered at the time appeared a universal right of children to education. ${ }^{42}$
\end{abstract}

Music was professionalized first through the ambition of Prince Miloš Obrenović to form a court orchestra after the fashion of European courts of the 1830s, after the hatt-i sharif and a legal basis for spreading education. It was followed by the arrival of Kornelije Stanković (1831-1865) and the development of instrumental music in our country happened during the reign of Mihailo Obrenović and the mentioned "accelerated education process". Music life of the $19^{\text {th }}$ century Serbia was almost completely in the hands of Czechs. ${ }^{43}$ Those were actually the citizens from the northern parts of the Austro-Hungarian monarchy, most often educated at the Music Conservatory or the Organ school in Prague, who, in search of available jobs, came to less developed, southern parts. ${ }^{44}$ Actually, regarding music education the whole $19^{\text {th }}$ century is marked by the lack of the local staff, so apart from Czechs musical teachers were coming from northern parts of Austro-Hungary, but also some Serbs named prečani arrived. ${ }^{45}$

The founder of music education and military/court instrumental performing in the Principality of Serbia was a Jew from Sombor, Josif Šlezinger. Active in many military bands of the Austro-Hungarian monarchy, Šlezinger came to Serbia first to the home of Jevrem Obrenović and subsequently to the court in Kragujevac, where he formed and led the Knjaževac-Serbian band, a military-court orchestra, for over three decades during numerous upheavals. The arrival of Kornelije Stanković in the 1850s had a decisive role in the development of a local variant of church music and the implementation of the so-called

\footnotetext{
42 Trgovčević 2003: 9.

${ }^{43}$ It should be stressed that the two most important educated musicians in the Principality of Serbia were foreigners: Josif Šlezinger (1794-1870), a Czech Jew from Sombor, and Aleksandar Morfidis Nisis (1803-1878), a Greek who was born and raised in Vienna. More details in: Đorđević 1950: 34; Krajačić 2003: 14-27; Đurić Klajn 1980.

${ }^{44}$ Pejović 1996: 51

${ }^{45}$ Migrations of "foreigners" from the north is a process that started during the brief period of Baroque Belgrade and that continued after the Serbian autonomy in the $19^{\text {th }}$ century. On migrations see also: Dajč and Vasiljević 2013: 90-92.
} 
"biedermeier" culture through the introduction of salon piano music, which was a way for cities in the Principality to try and join the dominant tide of the European court society's development regarding music. Also, the existence of orchestras is considered to be an important criterion in following the development of a certain environment regarding music and a profession of a military musician is expressed through instrumental music, especially having in mind the insistence on the fact that each military musician can play at least two instruments, while until 1923 and the establishment of the Belgrade Philharmonic Orchestra the civil sector mainly featured choirs performance. ${ }^{46}$ Still, in the $19^{\text {th }}$ century Serbia:

\footnotetext{
The process of establishing the civil class was going slower than in some developed countries and rural population grew faster than urban population. Throughout the century Serbia remained an agrarian country with the majority of population living in villages; between 1834 and 1910 the number of city inhabitants grew only from $6.1 \%$ to $13.1 \%$. ${ }^{47}$
}

Based on the data presented, it could not be expected that in such an agrarian society would the profession of military or any musicians be prominent or important. In such a context, those military musicians, with no war to fight, had to link to a life of urban environment where citizen and civil class was not even in the process of emerging, together with a difficult and complicated founding of institutions and spread of education. Therefore, it is important that the historian Trgovčević noticed even a "difference between the number of enrolled and educated", a discrepancy in education with a legal frame regarding the inclusion of citizens (and children), and a discrepancy between the capability of the state and staff that graduated from specialized schools. ${ }^{48}$

In the society of the Principality and later Kingdom of Serbia with less pronounced class differences, with a thin layer of urban population and the dominance of rural population, one should observe the profession of military musicians that, beside all listed criteria that would connect them with higher social strata. That process is hard to follow or understand without the migrations of "foreigners" from the Habsburg Empire. Among the foreigners that were gradually becoming "our foreigners" Czech musicians were the most numerous. Among them Josif Šlezinger, as the first professional musician and a Jew, was the most prominent one that started the process of professionalization of military music and the arrival of different kinds of "foreign" musicians. His arrival and carrier in Serbia started and marked a very important modernization process in the development of not only military music but also the spread of professional musicians in the society. That process of migration did not stop in the following period after the Great War but, on the contrary, just accelerated.

\footnotetext{
${ }^{46}$ See: Pejović 1991; Đurić Klajn 1977.

${ }^{47}$ Trgovčević 2003: 13.

${ }^{48}$ Ibid. $17-22$.
} 


\section{SOURCES:}

Arhiv Srbije, Fond Ministarstva prosvete (Archive of Serbia, Ministry od education fund), files 7, 8, $18,32,39$ i 49.

Narodna biblioteka Srbije, Odeljenje Specijalni fondovi (National Library of Serbia, Department Special funds), Archive of Dragutin Pokorni R-291, I-IX.

Vojni arhiv (Military archive), fond Vojske Kneževine/Kraljevine Srbije (The Army of Principality/Kingdom of Serbia fund) 1847-1920.

Arhiv Muzikološkog institutta SANU (Archives of Musicology institute of Serbian Academy of Sciences), Zaostavštine kompozitora (Legacies of composers) and Zbirke antologija (Anthology collections)

Narodni muzej Kruševca, Legat Stevana i Stanislava Biničkog (National Museum of Kruševac, Legacy of Stevan and Stanislav Binički)

\section{REFERENCES:}

Berendt, I. T. History Derailed: Central and Eastern Europe in the Long Ninenteenth Century, Berkeley: University of California Press, 2003.

Bjelajac, M. S. Jugoslovensko iskustvo sa multietničkom armijom 1918-1991, Beograd: Udruženje za društvenu istoriju, 1999.

Bjelajac, M. Vojska Kraljevine Srba, Hrvata i Slovenaca 1918-1921, Beograd: Narodna knjiga, 1988. 'Ženidbe oficira srpske i jugoslovenske vojske 1881-1941. Planirano stvaranje elite', Godišnjak za društvenu istoriju, 1, 1995), 22-41.

. 'Porodična tradicija vojnog poziva u Srbiji - Vojna elita 1804-1941', Godišnjak za društvenu istoriju, 1-2, 1996, 84-94.

Chirot, D. (ed.) The Origins of Backwardness in Eastern Europe: Economics and Politics from the Middle Ages Until the Early Twentieth Century, Berkeley and Los Angeles: University of California Press, 1991.

Čapo, H. 'Former Austro-Hungarian officers in the Army of the Kingdom of Serbs, Croats and Slovenes/Yugoslavia', Review of Croatian History, 1, 2009, 113-136.

Čalić, M.Ž. Socijalna istorija Srbije 1815-1941, Beograd: Klio, 2004.

Dajč, H. and Vasiljević, M. 'Status Jevreja u osmanskom i habzburškom Beogradu (XVII-XVIII vek): Stranci, manjine ili saradnici?', Limes plus, 2/2013, 85-104.

Deák, I. Beyond Nationalism: A Social And Political History Of The Habsburg Officer Corps 18481918, Oxford - New York - Toronto: Oxford University Press, 1990.

Gavrilović, M. Muzičko obrazovanje kao segment kulturnog razvoja grada Niša (1827-1914), doktorska disertacija. Novi Sad: Univerzitet umetnosti, 2012.

Gajić, M. 'Some issues of studying the activities of Czech musicians in Serbia in the 19th century' Musicological Annual/Muzikološki zbornik, XLV/1, 2009, 65-74.

Đorđević, V.R. Prilozi biografijama srpskih muzičara. Beograd: SANU, 1950.

Đurić Klajn, S. Beogradska filharmonija 1923-1979, Beograd: Beogradska filharmonija, 1977. . Akordi prošlosti, Beograd: Nolit, 1980.

Huntington, S. P. The Soldier and the State: The Theory and Politics of Civil-Military Relations. Cambridge, Massachusetts: The Belknap Press of the Harvard University Press, 1985.

Krajačić, G. Vojna muzika i muzičari: 1831-1945. Beograd: Vojska, 2003.

Lazić, M. Čekajući kapitalizam, Beograd: Službeni glasnik, 2012.

Mitrović, A. Srbija u Prvom svetskom ratu, Belgrade: Stubovi kulture, 2004. 
Marković, R. Vojska i naoružanje Srbije kneza Miloša, Beograd: SANU, 1957.

Pejović, R. Srpsko muzičko izvođaštvo romantičarskog doba, Beograd: Univerzitet umetnosti, 1991. . 'Češki muzičari u srpskom muzičkom životu (1844-1918)', Novi zvuk. Internacionalni časopis za muziku, 8, 1996, 51-58.

. 'Češki muzičari u srpskom muzičkom životu (1844-1918) II', Novi zvuk. Internacionalni časopis za muziku, 9, 1997, 65-74.

Perović, L. (ed.) Srbija u modernizacijskim procesima XX veka, Beograd: Institut za noviju istoriju Srbije, 2001.

Petranović, B. Istorija Jugoslavije, 1918-1988, I tom. Beograd: Nolit, 1988.

Ratković Kostić, S. B. Evropeizacija srpske vojske 1878-1902, Beograd: Vojnoistorijski institut, 2007.

Stanković, Đ.Đ. Nikola Pašić i jugoslovensko pitanje, knj. 1. Beograd: BIGZ, 1985.

Stojanović, D. Kaldrma i asfalt: Urbanizacija i evropeizacija beograda 1890-1914, Beograd: Udruženje za društvenu istoriju, 2008.

. Ulje na vodi: Ogledi iz istorije sadašnjosti Srbije, Beograd: Peščanik, 2010.

Tomašević, K. 'Contribution of Czech Musicians to the Serbian Music in the 19th Century', Musicological Annual/Muzikološki zbornik, XLII/1, 2006, 127-137.

Trgovčević, Lj. Planirana elita: o studentima iz Srbije na evropskim univerzitetima u 19. veku, Beograd: Istorijski institut, 2003.

. Naučnici Srbije i stvaranje jugoslovenske države, 1914-1920, Beograd: Narodna knjiga, 1986. j. Obrazovanje kao činilac modernizacije Srbije u XIX veku: analitička skica. 1994.

Vasiljević, M. 'A 'Quiet African Episode' for the Serbian Army in the Great War: The Band of the Cavalry Division and Dragutin F. Pokorni in North Africa (1916-1918)', New Sound, 43, 2014, $123-156$.

. 'Srpske vojne muzike u zemljama saveznika tokom Velikog rata (1916-1918)', Vojnoistorijski glasnik, 2, 2014, 20-41.

Vesić, I. 'Davorin Jenko, „,naš stranac” u kulturnom životu Beograda (1865-1914): Kontradiktornosti etničkog koncepta nacionalnog identiteta, Limes plus, 2/2013, 185-196. 


\section{МАЈА ВАСИЉЕВИЋ \\ ХАРИС ДАЈЧ \\ Универзитет у Београду, Филозофски факултет \\ ИЗМЕЪУ ДВОРСКЕ, ЦИВИЛНЕ И ВОЈНЕ СЛУЖБЕ: ВОЈНИ МУЗИЧАРИ У КНЕЖЕВИНИ И КРАЉЕВИНИ СРБИЈИ}

\section{Резиме}

Кнежевина, а потом Краљевина Србија са малобројном грађанском класом и мањим социјалним разликама у односу на развијеније европске земље, била је једно од омиљених одредишта за професионалне војне музичаре Хабзбуршке монархије. Музичари „странци“ су у таквим условима могли лако доћи до посла али и остварити брзо друштвено напредовање. Чешки музичари су били најбројнији и најзначајнији међу новопридошлицама, док је улога Јосифа Шлезингера била посебно важна за разумевање њиховог значаја и утицаја. Модернизацијски токови, као и образовање међу војним музичарима у Србији немогуће је пратити без прецизног осврта на растући број војних музичара. Овај рад управо даје осврт на њихов значај у дугом периоду њихових миграција који су трајали до XX века.

Кључне речи: Краљевина Србија, војни музичари, Чеси, мањине, модернизација, цивилно-војни односи. 